\title{
PENGARUH INVESTASI, PENGELUARAN PEMERINTAH DAN \\ TENAGA KERJA TERHADAP PDRB KABUPATEN/KOTA \\ DI PROPINSI BANTEN TAHUN 2010-2014
}

\author{
Oleh: \\ Ahmad Jazuli Rahman \\ PT.Bank Mandiri (Persero) Tbk Cabang Pasuruan Bangil \\ Aris Soelistyo \\ Syamsul Hadi \\ Fakultas Ekonomi dan Bisnis - Universitas Muhammadiyah Malang \\ E-mail: juliahmad031@gmail.com
}

\begin{abstract}
The purpose of the study was to determine the effect of variable investment (domestic and foreign), Government Expenditure, Labor (Labor Force Works) for the Gross Regional Domestic Product in Banten Province. The analysis tool used regression panel data. the test results obtained deteminasi coefficient $R \wedge 2$ for the fixed effect model of 0.9987. This showed that the ability of independent variables in explaining the dependent variable of $99.87 \%$. The results of the research study concluded that Investment, Government Expenditures and Labor was positive and significant impact on the Gross Regional Domestic Product with the results of Statistics $3.55 \mathrm{~F}$ more large than $F$ table is 2.38. While the partial test results showed that investment and government expenditure was a significant and positive effect while the labor was negative effect on the Gross Regional Domestic Product.
\end{abstract}

Keywords: Investment, Government Expenditure, Labor, PDRB

\begin{abstract}
ABSTRAK
Tujuan penelitian adalah untuk mengetahui pengaruh variabel Investasi (PMA dan PMDN), Pengeluaran Pemerintah, Tenaga Kerja (Angkatan Kerja yang Bekerja) terhadap Produk Domestik Regional Bruto (PDRB) di Provinsi Banten. Alat analisis yang digunakan adalah regresi data panel. dari hasil pengujian diperoleh nilai koefisien deteminasi $R^{\wedge} 2$ untuk model fixed effect sebesar 0,9987. Hal ini menunjukan bahwa kemampuan variabel bebas dalam menjelaskan variabel dependen sebesar 99,87\%. Hasil penelitian penelitian menyimpulkan bahwa secara serentak Investasi, Pengeluaran Pemerintah dan Tenaga Kerja berpengaruh positif dan signifikan terhadap Produk Domestik Regional Bruto (PDRB) dengan hasil F Statistik 3,55 lebih besar dari F tabel yaitu 2,38. Sedangkan hasil uji parsial menunjukan bahwa investasi dan pengeluaran pemerintah berpengaruh positif dan siginifikan sedangkan tenaga kerja berpengaruh negatif terhadap Produk Domestik Regional Bruto (PDRB).
\end{abstract}

Kata kunci: Investasi, Pengeluaran Pemerintah, Tenaga Kerja, PDRB 


\section{PENDAHULUAN}

Produk Domestik Regional Bruto (PDRB) menjadi tolok ukur pertumbuhan ekonomi di suatu daerah. Terjadinya kenaikan atau penurunan PDRB mengindikasikan terjadinya kenaikan atau penurunan dalam proses produksi barang dan jasa yang dihasilkan suatu daerah tertentu. Konsumsi pemerintah, pembentukan modal dan perubahan tenaga kerja adalah komponen yang mempengaruhi besaran nilai tersebut. Sehigga terjadinya kenaikan PDRB menunjukan kegairahan ekonomi bergerak dan berekspansi sehingga akan mempengaruhi pertumbuhan ekonomi di daerah tersebut.

Pertumbuhan ekonomi adalah salah satu alat ukur untuk melihat kondisi perekonomian di suatu wilayah. Penyelenggaraan pemerintah daerah sebagai sub sistem negara dimaksudkan untuk meningkatkan daya guna dan hasil guna peneyelenggaraan pemerintahan dan pelayanan masyarakat. Sebagai daerah otonom Kabupaten/Kota untuk bertindak sebagai "motor" sedangkan pemerintah Propinsi sebagai koordinator mempunyai kewenangan dan tanggung jawab menyelenggarakan

kepentingan

masyarakat.

Pemberlakuan Undang-

undang Nomor 32 Pasal 10 Ayat (5) Tahun 2004 tentang pelimpahan sebagian wewenang pemerintah daerah untuk mengatur dan menyelenggarakan urusan rumah tangga sendiri dalam rangka pembangunan nasional Negara Rebuplik Indonesia dan pemberlakuan Undang-undang Nomor 33 Pasal 4 Ayat (4) Tahun 2004 tentang perimbangan keuangan antara pemerintah pusat dan pemerintah daerah, diharapkan bisa memotifasi peningkatan kreatifitas dan inisiatif untuk lebih menggali dan mengembangkan potensi-potensi yang dimiliki oleh tiap-tiap daerah dan dilaksanakan secara terpadu, serasi dan terarah agar pembangunan disetiap daerah dapat benar-benar sesuai dengan prioritas dan potensi daerah (Jhingan, 1999 dalam Yunarko, 2007).

Propinsi Banten merupakan bentukan propinsi baru hasil pemekaran Jawa Barat pada tahun 2000 dan menjadi propinsi ke-28 di Indonesia berdasarkan Undang- 
undang Republik Indonesia Nomor 23 Tahun 2000. Terletak berbatasan dengan ibukota negara DKI jakarta dan Propinsi Jawa Barat membuat Propinsi Banten menjadi daerah strategis. Dengan keunggulan lokasi yang strategis perekonomian Banten bergerak cepat dan tumbuh dari tahun ke tahun.

Berdasarkan hasil pemekaran tersebut, saat ini Provinsi Banten memiliki 8 daerah administrasi yaitu terdiri dari 4 kabupaten dan 4 kota dan kota serang adalah ibukota provinsi. Keempat kabupaten tersebut adalah Tangerang, Serang, Pandeglang dan Lebak, sedangkan keempat kota yaitu kota tangerang kota, serang, cilegon dan kota Tangerang Selata. Kota Serang dan Kota Tangerang Selatan merupakan daerah baru hasil pemekaran pada tahun 2008 dan 2009.

Ditinjau dari sumber daya yang dimiliki, Propinsi Banten mempunyai kemungkinan yang sangat besar untuk aktifitas penanaman modal khususnya Penanaman Modal Asing (PMA) karena banyaknya tersedia berbagai bahan mentah dari berbagai sektor seperti sektor pertanian, perkebunan dan juga potensi daerah yang dijadikan objek wisata sehingga potensi-potensi daerah ini diberdayakan maka sangat besar manfaatnya dalam menghasilkan devisa negara dan juga menunjang terciptanya kegiatan ekonomi disekitar daerah tersebut yang dapat meningkatkan pendapatan masyarakat setempat.

Pengeluaran pemerintah daerah diukur dari total belanja rutin dan belanja pembangunan yang dialokasikan dalam anggaran daerah. Semakin besar pengeluaran pemerintah daerah yang produktif maka semakin memperbesar tingkat perekonomian suatu daerah (Wibisono, 2003).

Kebijakan yang yang dituangkan dalam APBD memerlukan perhatian terutama dalam hal pendistribusian anggaran sehingga dapat terciptanya sumber-sumber pendapatan baru bagi daerah. Kebijakan pengeluaran pemerintah yang secara langsung dapat mendorong pertumbuhan adalah belanja pembangunan karena variabel ini diwujudkan dalam bentuk pembangunan seperti jalan, jembatan dan sarana sektor ekonomi lainnya. 
Selama lebih dari 10 tahun pasca pemekaran wilayah atau pembentukan baru, Propinsi Banten telah mengalami peningkatan. Berdasarkan hal tersebut penulis merasa tertarik untuk mengkaji sejauh mana pengaruh realisasi Investasi yang terdiri dari Penanaman Modal Asing (PMA) dan realisasi Penanaman Modal Dalam Negeri (PMDN), pengeluaran pemerintah dan angkatan kerja yang bekerja terhadap PDRB Kabupaten/Kota di Propinsi Banten pada tahun 20102014.

\section{METODE PENELITIAN}

Jenis data yang digunakan dalam penelitian ini adalah data kuantitatif, dan sumber data yang digunakan adalah data sekunder yang diperoleh dari Badan Pusat Statistik Propinsi Banten berupa total pengeluaran pemerintah dan angkatan kerja yang bekerja tahun 2010-2014, dimana pengeluaran pemerintah diambil dari belanja langsung dan belanja tidak langsung dan tenaga kerja yaitu angkatan kerja yang bekerja pada tahun tersebutrealisasi investasi dari Badan Kordinasi Penanaman Modal (BKPM) Banten, dan data dalam bentuk publikasi oleh departemen terkait serta sumber lain yang terkait dengan penelitian ini.

\section{Analisis Data dan Uji Hipotesis}

Model Regresi Data Panel

Data yang digunakan dalam penelitian ini adalah data panel. Data panel adalah data yang diperoleh dengan menggabungkan antara cross section dan data time series. Data cross section dalam peneltian ini adalah data dari 8 kabupaten/kota di propinsi Banten, sedangkan data time series dalam penelitian ini adalah data tahun 2010 sampai dengan tahun 2014. Data tersebut diperoleh dari berbagai sumber antara lain Badan Pusat Statistik dna BKPM Propinsi Banten.

Menurut Gujarati (2003) teknik yang digunakan dalam data panel:

$$
\begin{aligned}
\log Y= & \beta_{0}+\beta_{1} \log X_{1}+\beta_{2} \log X_{2} \\
& +\beta_{3} \log X_{3}+e
\end{aligned}
$$

Dimana :

$Y=\mathrm{PDRB}$

$\beta 0=$ Konstanta

$\beta 1=$ Koefisien regresi dari $X 1$

$\beta 2=$ Koefisien regresi dari $\mathrm{X} 2$

$\beta 3=$ Koefisien regresi dari $\mathrm{X} 3$

$\mathrm{X}_{1}=$ Investasi

$\mathrm{X}_{2}=$ Pengeluaran Pemerintah

$\mathrm{X}_{3}=$ Tanaga Kerja

Error! Reference source not 
found.= Error Term

yang digunakan untuk menetukan teknik yang paling tepat untuk mengestimasi regresi data panel. yaitu uji Chow dan uji Hausman.

a. Uji Chow

Untuk mengetahui signifikan teknik Fixed Effect akan diuji menggunakan uji statistik F. Kegunaan uji statistik F yaitu untuk memilih antara metode OLS (Common Effect) tanpa variabel dummy atau metode Fixed Effect.

Uji statistik digunakan untuk mengetahui apakah teknik regresi data panel dengan Fixed Effect lebih baik dari model regresi data panel tanpa variabel dummy (Common Effect) dengan melihat Residual Sum of Squares (RSS).

Untuk menguji kedua hipotesis ini digunakan statistik F. nilai statistik $\mathrm{F}$ dihitung dari formula sebagai berikut:

$$
F=\frac{R^{2} / k}{\left(1-R^{2}\right) /(n-k-1)}
$$

Keterangan :

F : Rasio (KoefisienPenentu) found. :

Koefisien

Determinasi

$\mathrm{n}$ : Jumlah Observasi

$\mathrm{k}$ : Jumlah Variabel independen

$F$ hasil perhitungan ini dibandingkan dengan $F_{\text {tabel }}$ yang diperoleh dengan menggunakan tingkat resiko atau signifikan level 5\% atau dengan degree freedom $=n-k-1$ dengan criteria sebagai berikut:

Ho ditolak jikaF $\mathrm{F}_{\text {hitung }}>\mathrm{F}_{\text {tabel }}$

Ho diterima jikaF $\mathrm{F}_{\text {hitung }}<\mathrm{F}_{\text {tabel }}$

b. Uji Hausman

Dari hasil uji signifikan dua teknik diatas, diperoleh hasil bahwa teknik yang paling tepat yaitu Fixed Effect dan Random Effect. Untuk memilih antara teknik Fixed Effect atau Random Effect maka akan diuji kembali dengan uji Hausman. Kegunaan uji Hausman yaitu untuk memilih antara Fixed Effect atau Random effect.

Uji Hausman digunakan apabila metode Fixed Effect dan Random Effect lebih baik dari metode OLS (Common Effect).

Error! Reference source not 
Dari beberapa teknik yang digunakan, maka dapat disimpulkan bahwa metode yang paling tepat dalam penelitian ini adalah Fixed Effect. Hasil pengolahan data Fixed Effect menunjukkan bahwa persamaan regresi data panel antara Investasi, Pengeluaran Pemerintah, Tenaga Kerja berpengaruh signifikan terhadap PDRB. Selain itu nilai intercept berbeda pada masingmasing kabupaten dan kota menunjukkan keunikan model tersebut. intercept masing-masing kabupaten dan kota di Provinsi Banten berdasarkan rankingnya, pada teknik fixed effect. Maka peringkat intercept dari estimasi regresi data panel dengan pilihan penggunaan model fixed effect yang merupakan sebagai metode yang tepat.

\section{Pemilihan Teknik Estimasi Regresi}

\section{Data Panel}

\section{a. Uji Chow}

Uji Chow dilakukan untuk memilih antara teknik Common Effect dan Fixed Effect. Dari hasil pengujian dapat diketahui probabilitas cross section $\mathrm{F}$ sebesar $0,0000 \leq$ dari pada $\alpha=$
5\%. Dengan demikian pengambilan keputusan adalah menolak H0 dan menerima $\mathrm{Ha}$ yaitu model yang digunakan adalah Fixed Effect Model.

\section{Tabel 1. Hasil Uji Chow}

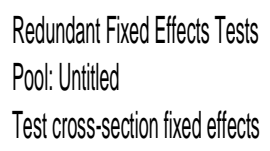

\begin{tabular}{lrrr}
\hline \hline Eftects Test & Statistic & d.f. & Prob. \\
\hline \hline Cross-section F & 1466.877357 & $(7,29)$ & 0.0000 \\
Cross-section Chi-square & 234.893031 & 7 & 0.0000
\end{tabular}

Sumber: Eviews9 2015 (data diolah

v. บgเ numsmun

Tabel 2. Hasil Uji Hausman

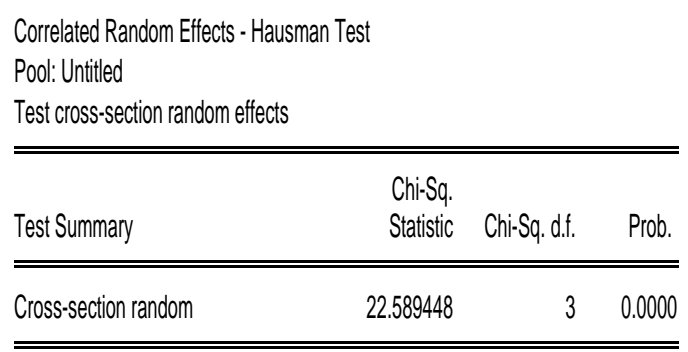

Sumber: Eviews9 2015 (data diolah

Sumber: Eviews9 2015 (data diolah

Random Effect. Dari hasil pengujian dapat diketahui probabilitas cross section random sebesar $0,0000 \leq$ dari pada $\alpha=5 \%$. Dengan hasil tersebut menolak H0 dan menerima Ha yaitu model yang digunakan adalah Fixed Effect dalam penelitian ini. 
Tabel 3. Hasil Analisis Regresi (Model Fixed Effect)

\begin{tabular}{|c|c|c|c|c|c|}
\hline Variable & Coefficient & Std. Error & t-Statistic & t-Tabel & Prob \\
\hline Investasi & 0.001325 & 0.000605 & 2.189547 & 1,690 & 0.0368 \\
\hline pengeluaran & 0.316287 & 0.017854 & 17.71518 & 1,690 & 0.0000 \\
\hline \multicolumn{6}{|l|}{ Pemerintah } \\
\hline Tenaga Kerja & -0.049150 & 0.093689 & -0.524607 & 1,690 & 0.6038 \\
\hline
\end{tabular}

Sumber: Eviews9 2015 (data diolah)

\section{b. Pengeluaran Pemerintah $\left(\mathbf{X}_{2}\right)$}

\section{a. Investasi $\left(\mathrm{X}_{1}\right)$}

Variabel Investasi $\left(\mathrm{X}_{1}\right)$ memiliki nilai $\mathrm{t}$ hitung sebesar 2,189547 dan nilai probabilitas sebesar 0.0368. Hal ini berarti nilai t hitung sebesar $(2,189547)$ $\geq \mathrm{t}$ tabel (1.690) dan nilai probabilitas $0.0368<\alpha=5 \%$ $(0,05)$ maka Ho ditolak dan Ha diteriama, dengan demikian dapat disimpulan bahwa Investasi $\left(\mathrm{X}_{1}\right)$ secara parsial berpengaruh positif dan signifikan terhadap PDRB (Y). Yang berarti bahwa setiap adanya kenaikan nilai investasi maka akan menaikan PDRB Propinsi Banten. Hal ini dikarenakan Kabupaten/Kota di Propinsi Banten mampu menyerap dan merealisasikan setiap investasi yang masuk.
Variabel

Pengeluaran

Pemerintah

$\left(\mathrm{X}_{2}\right.$ Error!

\section{Reference source not found.}

memiliki nilai t hitung sebesar 17,71518 dan nilai probabilitas sebesar 0.0000. Hal ini berarti nilai t hitung sebesar $(17,71518)$ $\leq \mathrm{t}$ tabel (1.690) dan nilai probabilitas $0.0000<\alpha=5 \%$ $(0,05)$ maka Ho ditolak dan Ha diterima, dengan demikian dapat disimpulan bahwa variabel Pengeluaran Pemerintah $\left(\mathrm{X}_{2}\right)$ secara parsial berpengaruh positif dan signifikan terhadap PDRB (Y). Hal ini dikarenakan Anggaran belanja pemerintah daerah khususnya di belanja pembangunan mampu di maksimalkan sehingga mendorong pada sektor-sektor 
yang tercantum dalam PDRB

Kabupatn/Kota di Propinsi

Banten.

\section{c. Variabel Tenaga Kerja $\left(\mathbf{X}_{3}\right)$}

Variabel Tenaga Kerja

$\left(\mathrm{X}_{3}\right)$ memiliki nilai $\mathrm{t}$ hitung sebesar -0,524607 dan nilai probabilitas sebesar 0,6038 .

Hal ini berarti nilai $t$ hitung sebesar $(-0,524607) \leq \mathrm{t}$ tabel (1.690) dan nilai probabilitas $0,6038>\alpha=5 \%(0,05)$ maka Ho diterima dan Ha ditolak, dengan demikian dapat disimpulkan bahwa variabel Investasi $\left(\mathrm{X}_{3}\right)$ secara parsial berpengaruh negatif dan tidak signifikan terhadap PDRB (Y). Hal tersebut dikarenakan minimnya keahlian tenaga kerja sehingga semakin banyak tenaga kerja namun output tetap bahkan berkurang hal ini berakibat pada pertumbuhan nilai PDRB yang didalamnya terdapat sektorsektor seperti sektor pertanian, pertambangan dan lain-lain.

Nilai F statistik lebih besar dari nilai $F$ tabel dengan Nilai $F$ hitung $(3,55)>F$ tabel $(2,38)$, hal ini berarti bahwa Ha diterima dan $\mathrm{Ho}$ ditolak. Dapat disimpulkan bahwa variabel bebas (Investasi, Pengeluaran Pemerintah, dan Tenaga Kerja) secara simultan berpengaruh signifikan terhadap variabel terikat (PDRB)

\section{KESIMPULAN}

Dari penelitian yang dilakukan maka dapat disimpulkan bahwa jumlah investasi dilihat dari total jumlah investasi baik PMA maupun PMDN dan pengeluaran pemerintah di 8 Kabupaten/Kota provinsi Banten tahun 2010-2014 berpengaruh positif dan signifikan terhadap pertumbuhan PDRB di Provinsi Banten. Dimana ketika jumlah investasi bertambah akan mempengaruhi besaran PDRB di Propinsi Banten.

Pengeluaran pemerintah dalam APBD baik pengeluaran langsung maupun tidak langsung dalam penelitian ini menunjukan hasil yang positif dan signifikan yang berarti semakin besar pengeluaran pemerintah maka pertumbuhan PDRB akan semakin meningkat.

Sedangkan Tenaga Kerja Berpengaruh Negatif terhadap pertumbuhan PDRB yang berarti ketika naiknya jumlah tenaga kerja 
jangka panjang akan menurunkan jumlah PDRB hal ini dikarenakan di beberapa daerah seperti lebak dan pandeglang yang unggul dalam sektor pertanian yang tidak dibarengi dengan luas tanah dan kualitas tenaga kerja sehingga bertambahnya tenaga kerja justru akan menurunkan jumlah PDRB di daerah tersebut.

Secara keseluruhan dalam penelitian ini menunjukan bahwa variabel Investasi, Pengeluaran Pemerintah dan Tenaga Kerja secara bersama-sama berpengaruh terhadap PDRB Kabupaten/Kota di Propinsi Banten hal tersebut tercermin pada $\mathrm{F}$ tabel lebih besar daripada F statistik.

\section{SARAN}

Pemerintah daerah diharapkan dapat menarik investasi dengan cara menciptakan iklim investasi yang kondusif, penyederhanaan proses perizinan, menjaga stabilitas ekonomi serta memperbaiki sarana dan prasarana infrastruktur sehingga penanaman investasi lebih merata ke berbagai wilayah yang di Provinsi Banten.

Begitu juga dengan tenaga kerja pemerintah daerah diharapkan dapat meningkatkan produktivitas tenaga kerja melalui peningkatan alokasi anggaran untuk pendidikan guna mempertinggi kualitas tenaga kerja, memberikan keterampilan bagi tenaga kerja serta memperluas kesempatan kerja sehingga output meningkat yang pada akhirnya dapat memacu PDRB di Provinsi Banten.

\section{Daftar Pustaka}

Arsyad Mohammad. 1987. Teori

Ekonomi dan Kebijaksanaan Pembangunan Daerah, dalam Hendra Asmara, Jakarta:PT.Gramedia.

Donny Adventua Silalahi. 2012. Analisis Pengaruh PDRB, Tingkat Investasi, dan Tingkat angkatan kerja terhadap tingkat kemiskinan di Sumatera Utara. Pambudi Wicaksono. 2013 Analisis Pertumbuhan Ekonomi dan Faktor-Faktor yang Mempengaruhi (Studi Kasus: kabupaten/kota di Provinsi Jawa Tengah.

Dumairy. 1997. Perekonomia Indoneisa. Jakarta: Penerbit Erlangga.

Banten Dalam Angka 2015 (Gambaran Umum Kondisi Daerah) 
Wahyani Putri Ayu Gusti I, Pengaruh

Pemerintah Dan Investasi

Terhadap Pertumbuhan

Ekonomidan Kesenjangan

Pendapatan Kabupaten/Kota di

Provinsi Bali, Jurnal Ekonomi

dan Bisnis Universitas Udayana

Sung Tai. 1997. " The Role of Local

Public Sectors in Regional

Growth" Asian economic journal, vol.11

Mankiw, $\quad$ N.Gregory.2000.Teori

Makro Ekonomi. Jakarta :

Penerbt Erlangga

Kuncoro Mudrajad, 1997, Ekonomi

Pembangunan : Teori, Masalah

dan Kebijakan, Yogyakarta, YKPN

Manuaba, B.P.2006. Pengaruh Pengeluaran Pemerintah, pertumbuhan investasi, dan ekspor terhadap Produk

Domestik Regional Bruto (PDRB) kabupaten Badung. Tesis MEP UNUD.

Munawwaroh. 2013. Faktor-Faktor yang Mempengaruhi Kualitas Sumberdaya Manusia dan Perekonomian kabupaten/kota di Provinsi Jambi. Jurnal Kajian 03 (II). HIm136-154

Mankiw, N Gregory, 2000, Teori Makro Ekonomi, Edisi Keempat, Penerbit Erlangga

Republik Indonesia, 2004. Undangundang Nomor 32 Tahun 2004 tentang Pemerintah Daerah.

Republik Indonesia, 2004. Undangundang Nomor 33 Tahun 2004 tentang Perimbangan Keuangan antara Pemerintah Pusat dan Daera 